Article

\title{
Sustainability Analysis of Prosopis juliflora (Sw.) DC Based Restoration of Degraded Land in North India
}

\author{
Sheikh Adil Edrisi ${ }^{1}$, Ali El-Keblawy ${ }^{2}\left(\mathbb{D}\right.$ and Purushothaman Chirakkuzhyil Abhilash ${ }^{1, *}$ (i) \\ 1 Institute of Environment \& Sustainable Development, Banaras Hindu University, Varanasi-221005, \\ Uttar Pradesh, India; sheikhadiledrisi@gmail.com (S.A.E.); pca.iesd@bhu.ac.in (P.C.A.) \\ 2 Department of Applied Biology, Faculty of Science, University of Sharjah, P.O. Box, 27272 Sharjah, UAE; \\ akeblawy@sharjah.ac.ae (A.E.-K.) \\ * Correspondence: pca.iesd@bhu.ac.in; Tel.: +91-9415644280
}

Received: 25 January 2020; Accepted: 19 February 2020; Published: 21 February 2020

Abstract: Restoration of marginal and degraded lands is essential for regaining biodiversity and ecosystems services, and thereby attaining UN-Sustainable Development Goals. During the last few decades, many fast growing and hardy trees have been introduced worldwide to restore the marginal and degraded lands for ecosystem stability. Unfortunately, most of these introduced species have become invasive and invaded the nearby productive systems, leading to significant biodiversity loss and land degradation. Therefore, it is imperative to conduct a sustainability analysis of the introduced species for necessary course correction and also for preventing the future utilisation of such species for land restoration. With this backdrop, the present study was conducted to analyse the socio-ecological impacts of a widely used species, i.e., Prosopis juliflora (Sw.) DC based restoration of degraded land of Lucknow, North India. For this, ecological (soil quality and plant biodiversity) and social (livelihood) indicators have been studied over a period of two years (2015-16) through direct field sampling and questionnaire-based surveys. While there was a positive difference $(p<$ 0.01 ) in the key physico-chemical properties of the P. juliflora-invaded soil than the non-invaded site, the belowground microbial load was significantly lower $\left(19.46 \times 10^{6} \mathrm{~g}^{-1}\right.$ of soil) in invaded land as compared to the non-invaded one $\left(31.01 \times 10^{6} \mathrm{~g}^{-1}\right)$. Additionally, the invasion of $P$. juliflora had significantly reduced the biodiversity by displacing the local flora such as Achyranthes aspera L., Amaranthus spinosus L., Cynodon dactylon (L.) Pers, Euphorbia hirta L., etc. The invaded area had only eight plant species having an effective number of species (ENS) of 7.2, whereas the non-invaded area had the presence of 26 plant species with an ENS of 23.8. Although the local people utilised P. juliflora as fuelwood mostly during summer and winter seasons, the invasion resulted in a fodder deficit of $419.97 \mathrm{~kg}_{\text {household }}{ }^{-1} \mathrm{y}^{-1}$ leading to resource scarcity in the invaded area in comparison to the non-invaded area. Ecodistribution mapping clearly showed that $P$. juliflora is already found in most of the tropical and subtropical countries ( 103) including in India and has become invasive in many countries. Therefore, we recommend that $P$. juliflora must be wisely used for the land restoration programs targeted during the United Nations Decade of Ecosystem Restoration (2021-2030) as this species has invasive traits and thereby reduces the ecosystem sustainability of the invaded areas.

Keywords: biodiversity; degraded land; ecosystem services; international decade of ecosystem restoration; Prosopis juliflora; sustainability analysis; UN-sustainable development goals

\section{Introduction}

Sustainable management of the land resources is an important doctrine of environmental sustainability [1] and, therefore, this concept is gaining momentum not only because of its ecological, social and political ramifications [2] but also due to the fact that land is a finite resource and an 
essential life-supporting system of this planet. Therefore, utmost care should be taken to utilise various kinds of land for sustainable development. Unfortunately, the latest estimates suggest that almost one-third of the global land (24 to 30\%) is contaminated or degraded due to various natural and manmade activities $[3,4]$. Therefore, the restoration of degraded land is essential for regaining biodiversity and ecosystems services and thereby attaining United Nations-Sustainable Development Goals (UN-SDGs) (www.sustainabledevelopment.un.org). Moreover, the land restoration is a top priority during the 'United Nations Decade on Ecosystem Restoration' starting from 2021-30 (www.decadeonrestoration.org).

Degraded lands are less productive and commonly described as 'wastelands' , 'marginal lands', 'degraded lands', 'abandoned lands', 'contaminated lands', etc. Literature provides ample evidences regarding the efforts which are being made to improve the productivity of degraded lands [5-8]. Many national and international agencies are working on the improvement of such land types [9-11] including land degradation neutrality (LDN) and land restoration for attaining UN-SDGs [12-14]. According to UNCCD, LDN is a situation where there is no further degradation to the land system while enhancing the vitality, productivity and ecosystem services of the land system for meeting the food and nutritional demand of the current and future generations, and also for attaining ecosystem sustainability (www.unccd.int).

While land degradation is continuing across the world, there are many positive efforts are being operational at local, regional and global scale towards LDN and previous studies have already articulated various integrated measures for monitoring and restoring the vitality of degraded lands. For example, Tripathi et al. [5] proposed packages of practices based on biotechnological advancement for improving the productivity of marginal lands, whereas Dubey et al. [6] proposed strategies for harnessing plant-soil-microbe interactions as a low-input technology for restoring the fertility of degraded land under current and futuristic climatic conditions. Similarly, Edrisi et al. [7] proposed simplified measures to monitor the restoration of marginal and degraded lands at the regional level. The Indian Council of Agricultural Research (ICAR) has provided the estimates of such lands in India and suggested several adaptive measures to mitigate land degradation [9] whereas the The International Crops Research Institute for the Semi-Arid Tropics (ICRISAT) has contributed towards the biological reclamation of degraded lands in Niger [10]. The Global Partnership on Forest and Landscape Restoration (GPFLR) is another enterprise operational at global level for both financing and practising the restoration initiatives across the globe [11]. Furthermore, Keesstra et al. [12] suggested four inventive methods to attain LDN and developing suitable remediation techniques for addressing soil-related SDGs, whereas Tianjiao et al. [13] reported the effect of various land management practices and Novara et al. [14] studied the effect of sustainable farming on soil carbon recovery.

Among the various restoration methods, the plantation of fast-growing and multipurpose tree species is often considered as an amicable solution for the revitalization of marginal and degraded lands for multipurpose environmental benefits. Therefore, the tree species with economic importance, particularly with bioenergy production potential have a vital role in land restoration and soil carbon sequestration $[15,16]$. There are many fast-growing, tolerant and hardy species have been successfully introduced worldwide for the restoration of marginal and degraded lands and thereby improving the ecology of the degraded system and the livelihood of the affected communities. However, some of those species tend to be invasive and negatively affecting the local environment, livelihood and human health [17-20]. P. juliflora (Sw.) DC is one of such introduced species for the restoration of marginal and degraded lands in various countries [16,21,22]. Although there are some positive impacts of P. juliflora introduction in the arid [23] and semi-arid regions of the world [24,25], in most cases the introduction of $P$. juliflora resulted in biodiversity loss by the displacement of native plants [26], soil biodiversity $[25,27]$, and other ecosystem services (ESs) including the alteration of hydrological regimes [28,29] and reducing livelihood opportunities [27]. Although Prosopis is an important genus in the tropics and sub-tropics having 44 species, all of the species are not economically important [30]. Among the various species, P. juliflora is native to Central and South America and it is one of the 
world's worst invasive species [31]. While P. juliflora was introduced different parts of the world primarily to restore the degraded ecosystems and also to provide additional benefits to the rural community in the form of charcoal, fuelwood and construction materials, as well as to restore the degraded ecosystems [32], P. juliflora has invaded in many places around the world and imposes negative impacts on the ecology and socio-economy [33-35].

Two species of Prosopis, i.e., Prosopis cineraria and P. juliflora, are found in India. While Prosopis cineraria is native, P. juliflora become invasive and grows all over the country [25]. The inter-continental introduction of this genus started in the early 19th century and became widespread in the late 20th century (1940-90) [32]. The first introduction of P. juliflora in the Indian sub-continent is reported to occur in the Sindh region around 1857. Furthermore, the seeds were introduced in the Andhra Pradesh in 1877 on the request of Lt. Col. R.H. Bedome, Conservator, Forests of Northern Circle (Madras) to the Secretary of the state (Tamil Nadu) [30]. Several instances of introduction in the other parts of India by Col. Corbyn and R.N. Parker have been documented from 1879-1909. Moreover, this invasive plant was introduced in Rajasthan in around 1913 and the seeds were distributed to various neighbouring states. In 1940, the tree was given special status in Jodhpur (i.e., royal plant) for protection. Similarly, other forms of Prosopis spp. are also reported to have been introduced in India in the past, but unfortunately the records of their performances are not available [30].

While most of the introduction of P. juliflora was intentional, the accidental introduction has also occurred between the neighbouring countries [36-38]. As in the case of other countries, P. juliflora was introduced in India for (i) rehabilitating the marginal and degraded lands of India, (ii) stabilizing the sand-dunes, (iii) afforestation, (iv) as a fuelwood, (v) providing fodder and shade in the arid regions of India, (vi) regional greening, and (vii) ornamental purposes [30,36-41]. As of now, P. juliflora has been introduced in 103 countries across the world, and among these, 40\% of the introduction has become invasive including in India [32,42-45]. In this context, the present study was aimed to understand the (i) the current status of P. juliflora invasion across the world, and (ii) the socio-ecological impacts of $P$. juliflora invasion in a highly invaded area of Lucknow, North India by analysing the impact of P. juliflora invasion on soil quality, biodiversity, and livelihood.

\section{Materials and Methods}

\subsection{Study Area}

P. juliflora-invaded land of Lucknow district, Uttar Pradesh, North India $\left(26^{\circ} 53^{\prime} 29.4^{\prime \prime} \mathrm{N}\right.$, $80^{\circ} 58^{\prime} 45.7^{\prime \prime E}$ ) was selected for this study (Figure 1). The total geographic area of Lucknow district is $2528 \mathrm{~km}^{2}$ with mean elevation at $123 \mathrm{~m}$ from the sea level, having a warm humid and sub-tropical climatic condition (www.msmedikanpur.gov.in). The study area lies under the Chinhat block of the Lucknow district. The block represents a total area of $125.6 \mathrm{~km}^{2}$ under which an area of $22.09 \mathrm{~km}^{2}$ is barren and un-cultivable land or the area is under non-agricultural uses (Table 1). The study site receives mean annual precipitation of around $1010 \mathrm{~mm}$ whereas the mean annual temperature ranges from $20.51{ }^{\circ} \mathrm{C}$ to $37.09{ }^{\circ} \mathrm{C}$. The land-use pattern of the study site (both invaded and non-invaded area) falls under un-cultivable land. All the analyses regarding the soil quality, local biodiversity and the livelihood were conducted in both the sites and compared with each other. 


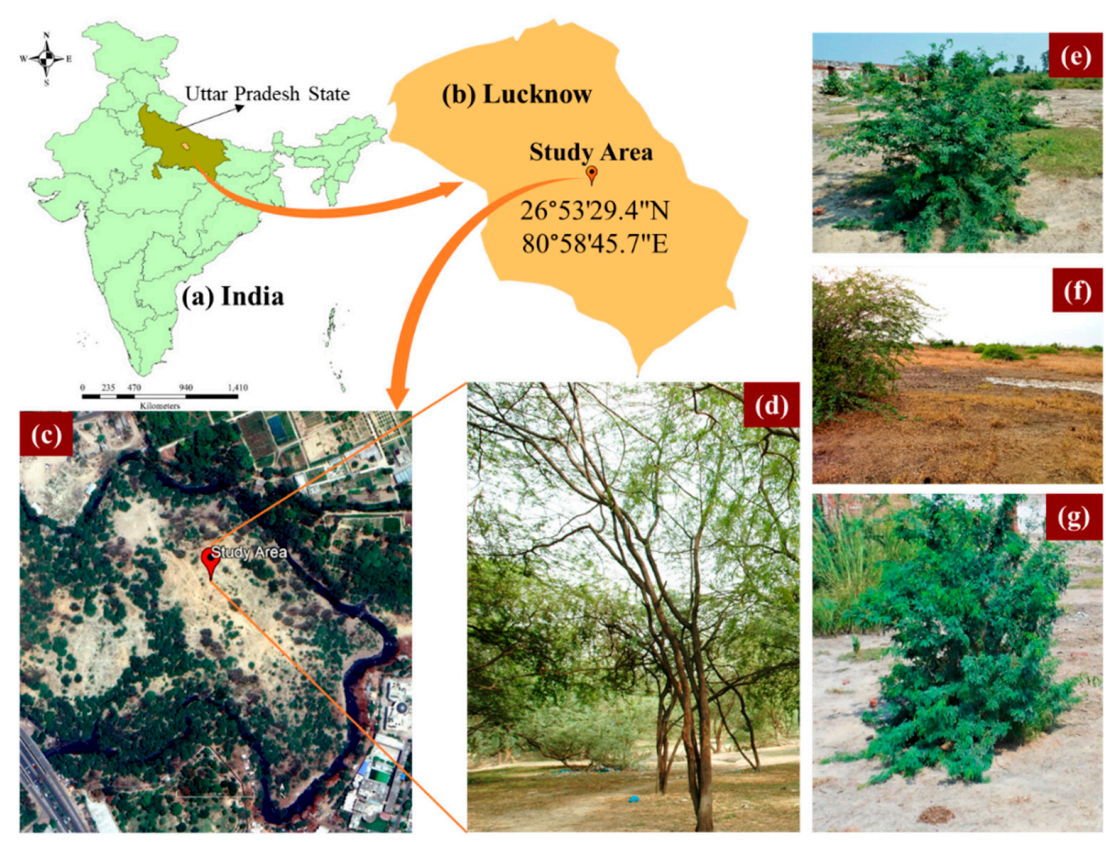

Figure 1. Geographical location of the study area: (a) India, (b) Lucknow, (c) Spatial imagery of the study area (source: Google Earth) (d) experimental field, (e-g) sub-sampling plots.

Table 1. General land-use and demographic profile of the study area (Block name: Chinhat, Tehsil name: Lucknow, District: Lucknow).

\begin{tabular}{|c|c|c|}
\hline S. No. & Land-Use of the Block* & (Area in ha) \\
\hline 1. & Total block area & $12,564.94$ \\
\hline 2. & Cultivable area & 5688.15 \\
\hline 3. & Forest area & 3.70 \\
\hline 4. & Area under non-agricultural uses & 1746.70 \\
\hline 5. & Barren and un-cultivable land & 462.40 \\
\hline 6. & Permanent pastures and other grazing lands & 74.20 \\
\hline 7. & Land under miscellaneous tree crops, etc. & 139.10 \\
\hline 8. & Culturable wasteland & 597.30 \\
\hline 9. & Fallow lands other than current fallows & 2398.9 \\
\hline 10. & Current fallows & 1455.40 \\
\hline \multicolumn{2}{|c|}{ Demography of the Block* } & (numbers) \\
\hline 11. & Number of households & 24,845 \\
\hline 12. & Total population & 137,251 \\
\hline \multicolumn{2}{|c|}{ Demography of study area (P. juliflora-invaded and non-invaded) ${ }^{\#}$} & (numbers) \\
\hline 13. & Households in $P$. juliflora-invaded area & 21 \\
\hline 14. & Households in non-invaded area & 36 \\
\hline 15. & Population in $P$. juliflora-invaded area & 129 \\
\hline 16 & Population in non-invaded area & 218 \\
\hline 17. & Livestock in $P$. juliflora-invaded area & 11 \\
\hline 18. & Livestock in non-invaded area & 30 \\
\hline
\end{tabular}

* District census handbook (www.censusindia.gov.in); \# from the field survey and interviews 


\subsection{Field Study and Soil Sampling}

The field study was conducted during the two consecutive years from 2015 to 2016 to analyse the impacts of $P$. juliflora on key socio-ecological parameters specifically the (i) soil quality, (ii) biodiversity and (iii) local livelihood. All the studied parameters have been compared with the non-invaded area. The size of the experimental field was $2400 \mathrm{~m}^{2}$ (Figure 1d), which was further divided into 6 sub-plots consisting an area of $400 \mathrm{~m}^{2}(20 \times 20 \mathrm{~m})$ to completely cover the experimental field (Figure 1e-g). The rhizospheric soil samples $(0-15 \mathrm{~cm})$ of the $P$. juliflora were collected randomly near the tree trunk in quadruplicates $(n=4)$ from invaded. Soil samples were also collected from non-invaded area as the control samples. The weight of each quadruplicate was reduced to $500 \mathrm{~g}$ via the conning-quartering method. The samples were then air-dried and sieved $(2 \mathrm{~mm})$ for further analyses as per the standard procedure mentioned elsewhere.

\subsection{Soil Analysis}

The physico-chemical and biological parameters of soil samples such as bulk density (BD), water holding capacity (WHC), pH, electrical conductivity (EC), cation exchange capacity (CEC), total organic carbon (TOC), soil organic matter (SOM), total nitrogen (TN), available nitrogen (AN), carbon to nitrogen ratio (C:N), total phosphorus (TP), microbial biomass carbon (MBC), microbial biomass nitrogen (MBN), soil dehydrogenase activity (SDA), bacterial colony forming units (CFU) for both the invaded as well as the control sites (open soils from non-invaded area) were done for the year 2015-16. The soil properties, particularly the $\mathrm{pH}, \mathrm{EC}, \mathrm{BD}, \mathrm{WHC}, \mathrm{CEC}, \mathrm{TOC}$ and SOM, were analysed as per the standard procedural protocols published elsewhere [46-49]. Furthermore, TN was determined through acid digestion (conc. $\mathrm{H}_{2} \mathrm{SO}_{4}$ and conc. $\mathrm{HNO}_{3}$ ) followed by the steam distillation method [50] and $\mathrm{AN}$ was estimated using $\mathrm{KMnO}_{4}$ solution followed by steam distillation [51], and C:N ratio was estimated as per the calculation. The TP was done by using the standard protocol published earlier [52]. MBC and MBN content was estimated by Vances et al. [53] and Brookes et al. [54]. Similarly, SDA was measured for all soil samples [55], and bacterial enumeration of CFU was carried out from the soil samples of both invaded as well as the non-invaded according to the standard procedure proposed earlier [56].

\subsection{Biodiversity Indices under P. juliflora-Invaded and Non-Invaded Areas}

The plant diversity of the experimental field was done by quadrat sampling method $(20 \times 20 \mathrm{~m})$. The relative density (RD) of each plant species, Shannon-Wiener biodiversity index $(\mathrm{H})$ and effective number of species were calculated by using the following formulae:

$$
\text { Relative density }(\mathrm{RD})(\%)=\frac{\text { number of individuals of a particular species }}{\text { number of individuals of all species }} \times 100
$$

The Shannon-Wiener biodiversity index $(\mathrm{H})$ :

$$
\mathrm{H}=-\sum_{\mathrm{i}=1}^{\mathrm{S}}\left(\mathrm{p}_{\mathrm{i}}\right)\left(\ln \mathrm{p}_{\mathrm{i}}\right)
$$

The effective number of species (ENS) was calculated from the results of the Equation (2) as:

$$
\mathrm{ENS}=\exp (\mathrm{H})
$$

\subsection{Analysis of P. juliflora Invasion on Local Livelihood}

The impacts of $P$. juliflora invasion on the local livelihood was assessed through the extensive field surveys and the interviews of the residents. For the survey, 63 respondents from 15 households ( 4 respondents from each household) of each study area (invaded and non-invaded) were selected by 
using the lottery-random sampling technique [57]. The age of the respondents varied from $25-56$ years. Further, the household dependence was also assessed regarding the services (resources) provided by this tree species in the form of either fuelwood, fodder, fencing or fibre and its prospects. The dependency of the residents with the $P$. juliflora was recorded through the semi-structured questionnaire-based survey (Table 2). The quantity of fuelwood required and its daily consumption by each selected household was estimated by the weight-applied survey method [58,59]. The yearly consumption of fuelwood was evaluated by integrating the fuelwood consumption in different seasons (summer, rainy and winter). Resources that are extracted from the P. juliflora-invaded area and utilised by the selected households were fuelwood, fodder, leaf litter and ground pods, etc.

Table 2. Information collected through the semi-structured questionnaire.

\begin{tabular}{|c|c|}
\hline Item & Content/Purpose of the Questions \\
\hline (A) Age and sex & Respondent's age and sex \\
\hline (B) Literacy level & $\begin{array}{l}\text { The literacy level of the respondent and their understanding } \\
\text { regarding Prosopis juliflora and other local/introduced species }\end{array}$ \\
\hline (C) Resource utilisation type & $\begin{array}{l}\text { The type of resources extracted/collected by the local residents from } \\
\text { both invaded and non-invaded areas } \\
\text { Fuelwood } \\
\text { Fodder } \\
\text { Medicinal } \\
\text { Fencing } \\
\text { Leaf litters } \\
\text { Fruits/Edibles } \\
\text { Other Utility }\end{array}$ \\
\hline $\begin{array}{l}\text { (D) Process of resource } \\
\text { extraction/collection }\end{array}$ & $\begin{array}{c}\text { The way by which the local residents extracted/collected/utilized the } \\
\text { resources from both invaded and non-invaded areas } \\
\text { Felling } \\
\text { Chopping } \\
\text { Lopping } \\
\text { Plucking } \\
\text { Grazing }\end{array}$ \\
\hline (E) Frequency of the extraction & $\begin{array}{l}\text { The frequency of the extraction/collection of the resources from both } \\
\text { invaded and non-invaded areas } \\
\text { Daily } \\
\text { Weekly } \\
\text { Fortnightly } \\
\text { Monthly } \\
\text { Once in a while } \\
\text { Seasonally } \\
\text { Annually }\end{array}$ \\
\hline (F) Duration of the extraction & $\begin{array}{l}\text { The duration of the extraction/collection of the resources from both } \\
\text { invaded and non-invaded areas } \\
\text { Summer } \\
\text { Winter } \\
\text { Rainy } \\
\text { Annual }\end{array}$ \\
\hline
\end{tabular}

\subsection{Invasion Mapping and Data Analysis}

The data for assessing the global distribution and invasion status of P. juliflora (i.e., native, naturalised and invasive) as well as its distribution in the Indian states (either invaded or facing the risk of invasion) was obtained from various literature [30,32,36,42], regional floras (e.g., Flora of India), and also by conducting extensive field surveys in various Indian states and the distribution and invasion maps were prepared accordingly. The distribution map is important for understanding the current status of this species and also for designing suitable management options accordingly. The maps were generated under ArcGIS Desktop 10.5 (copyright (C) 2016 ESRI, Redlands, California, USA) especially ESRI's ArcMap $^{\mathrm{TM}} 10.5$ (Build 6491) a software for the Windows operating system. For analysing the impact of $P$. juliflora invasion on soil quality, biodiversity and on the local livelihood, whole dataset of soil testing, biodiversity analysis and resource extraction were subjected to independent samples 
t-tests at the $99 \%$ confidence level $(p<0.001)$ by using Statistical Package for Social Science (SPSS) program for windows version 16.0.2 (SPSS Inc., Chicago, IL, USA) software [60,61].

\section{Results}

\subsection{The Current Status of P. juliflora Invasion: Global and Indian Scenario}

The analysis of the global (Figure 2a) and national invasion (Figure 2b) status of $P$. juliflora clearly shows that the extent of $P$. juliflora invasion is severe and that it is already widespread in most of the tropical and subtropical countries ( 103) and has become a global issue, including in the Indian sub-continent. While this plant species is native to Central and South America (extending the home range from southern Mexico to northern Peru including Venezuela, Colombia, Ecuador, Bolivia, Chile, Paraguay, Uruguay and Argentina), this species has now widely found in Africa and Asia-Pacific (Figure 2a) [32,42-45].
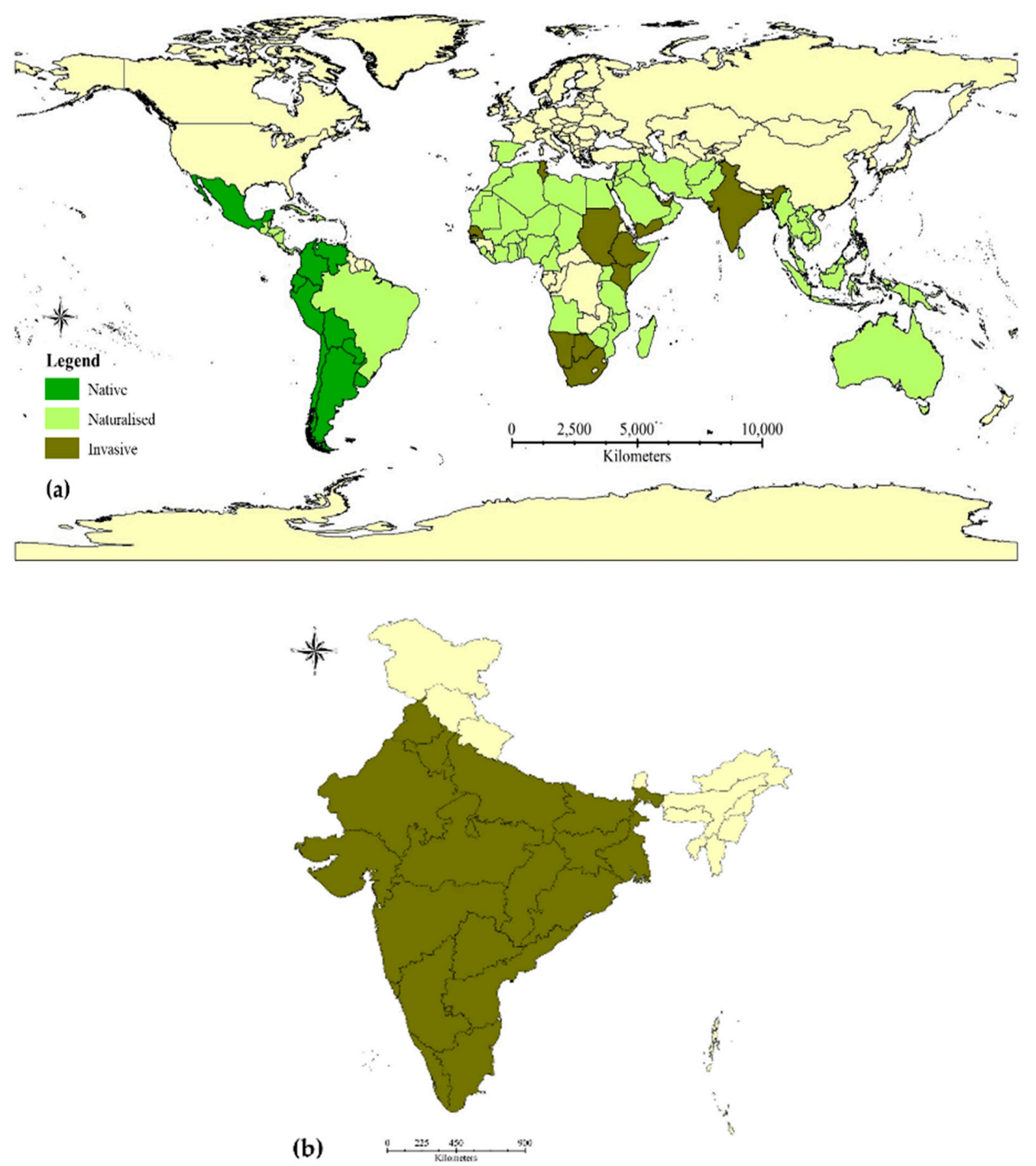

Figure 2. (a) Global distribution of $P$. juliflora showing its native range, naturalised habitat and the areas facing the risk of invasion, (b) Invasion status of P. juliflora in India. 
P. juliflora has been naturalised in the major parts of the world including the Brazil, North-Western Africa, Southern Africa, Middle East, and Western Asia (Figure 2a). Apart from its naturalised and invaded habitat, many other areas of the world are under the threat and risk of its invasion. These areas include mostly the Eastern Africa (Sudan, Ethiopia and Kenya) and Southern Africa (Botswana, Namibia and South Africa). Aside this, Senegal, Tunisia, Yemen, UAE and India are facing major threat of P. juliflora invasion [42-45]. In India, it has already invaded 18 Indian states excluding the Jammu and Kashmir, Himachal Pradesh and the major parts of Uttarakhand in northern India and also north-eastern states (Figure 2b).

\subsection{Effect of P. juliflora Invasion on Soil Quality}

The soil quality parameters of the P. juliflora-invaded and non-invaded areas are presented in Table 3. From the results (Table 3), it is clear that the quality of soil was somewhat better in the $P$. juliflora-invaded land of Lucknow in comparison to the open (non-invaded) area. The physico-chemical characteristics of $P$. juliflora soils such as $\mathrm{pH}, \mathrm{BD}$, and CEC were not significantly different $(p>0.01)$ except the WHC $(p<0.05)$ as compared to the soil samples from non-invaded area. The EC of the non-invaded soil was significantly higher $\left[0.27 \mathrm{ds} \mathrm{m}^{-1}(p<0.05)\right]$ as compared to the P. juliflora-invaded soils $\left(0.16 \mathrm{ds} \mathrm{m}^{-1}\right)$. However, the chemical properties like TOC, SOM, TN, AN, TP in the P. juliflora soils were significantly higher than the non-invaded area (Table 3), whereas the C:N ratio was 1.5 times lower in the invaded area as compared to the non-invaded area. Interestingly, the CFU counts were significantly higher in the non-invaded area (mean value as $29.81 \times 10^{6} \mathrm{~g}^{-1}$ of soil and $31.01 \times 10^{6} \mathrm{~g}^{-1}$ of soil during the years 2015 and 2016, respectively) as compared to the invaded region, which were $19.10 \times 10^{6} \mathrm{~g}^{-1}$ of soil and $19.46 \times 10^{6} \mathrm{~g}^{-1}$ of soil for the two consecutive sampling years, respectively. There was no significant difference in the MBC $(p>0.05)$ content of the two sites; however, there was a difference in the MBN $(p<0.05)$ between the two sites over the sampling period. SDA is another key indicator for monitoring microbial activity in soil [62]. As per the results, SDA was significantly higher, i.e., approximately there was a two-fold increase in the SDA of the soils of P. juliflora as compared to the non-invaded area (Table 3).

Table 3. Physico-chemical and biological properties of the soil collected from the rhizosphere of $P$. juliflora in the invaded area of Lucknow, India and also from the open area ( $n=4$; Mean \pm SD) in 2015 and 2016.

\begin{tabular}{ccc}
\hline Parameters & Invaded area & Non-invaded (Open Area) \\
\hline $\mathrm{pH}$ & $7.06 \pm 0.15$ & $7.05 \pm 0.13$ \\
\hline $\mathrm{EC}\left(\mathrm{ds} \mathrm{m}^{-1}\right)$ & $0.16 \pm 0.11$ & $0.27 \pm 0.04^{*}$ \\
\hline $\mathrm{BD}\left(\mathrm{g} \mathrm{cm}^{-3}\right)$ & $1.28 \pm 0.06$ & $1.30 \pm 0.04$ \\
\hline Water holding capacity $(\%)$ & $57.97 \pm 2.83^{*}$ & $41.22 \pm 0.50$ \\
\hline Cation Exchange Capacity $\left(\mathrm{cmol} \mathrm{kg}^{-1}\right)$ & $17.50 \pm 0.60$ & $16.77 \pm 0.41$ \\
\hline Total organic carbon $\left(\mathrm{g} \mathrm{kg}^{-1}\right)$ & $8.93 \pm 0.81^{*}$ & $5.01 \pm 0.42$ \\
\hline Soil organic matter $\left(\mathrm{g} \mathrm{kg}^{-1}\right)$ & $15.39 \pm 1.40^{*}$ & $8.64 \pm 0.72$ \\
\hline Total nitrogen $\left(\mathrm{g} \mathrm{kg}^{-1}\right)$ & $0.85 \pm 0.21^{* *}$ & $0.21 \pm 0.07$ \\
\hline Available nitrogen $\left(\mathrm{g} \mathrm{kg}^{-1}\right)$ & $0.31 \pm 0.05^{* *}$ & $0.09 \pm 0.04$ \\
\hline Total phosphorus $\left(\mathrm{g} \mathrm{kg}^{-1}\right)$ & $0.17 \pm 0.03^{* *}$ & $0.04 \pm 0.01$ \\
\hline C:N ratio & $10.94 \pm 2.37$ & $26.79 \pm 8.05^{* *}$ \\
\hline Microbial biomass carbon $\left(\mu \mathrm{g} \mathrm{g}^{-1}\right)$ & $127.20 \pm 12.08$ & $119.10 \pm 9.08$ \\
\hline Microbial biomass nitrogen $(\mu \mathrm{g} \mathrm{g})$ & $12.50 \pm 1.07^{*}$ & $9.46 \pm 1.00$ \\
\hline Colony forming unit $\left(10^{6} \mathrm{gg}^{-1}\right)$ & $19.28 \pm 0.80$ & $30.41 \pm 4.55^{*}$ \\
\hline Soil dehydrogenase activity $\left(\mu \mathrm{g} \mathrm{g}^{-1} \mathrm{~h}^{-1}\right)$ & $16.31 \pm 2.74^{*}$ & $8.75 \pm 0.69$ \\
\hline
\end{tabular}

Note: values with asterisks denote the significance in the respective row and derived from independent $t$-tests at $p \leq 0.01$. 


\subsection{Effect of P. juliflora Invasion on Local Plant Biodiversity}

The plant diversity of the invaded and non-invaded area is presented in Figure 3.

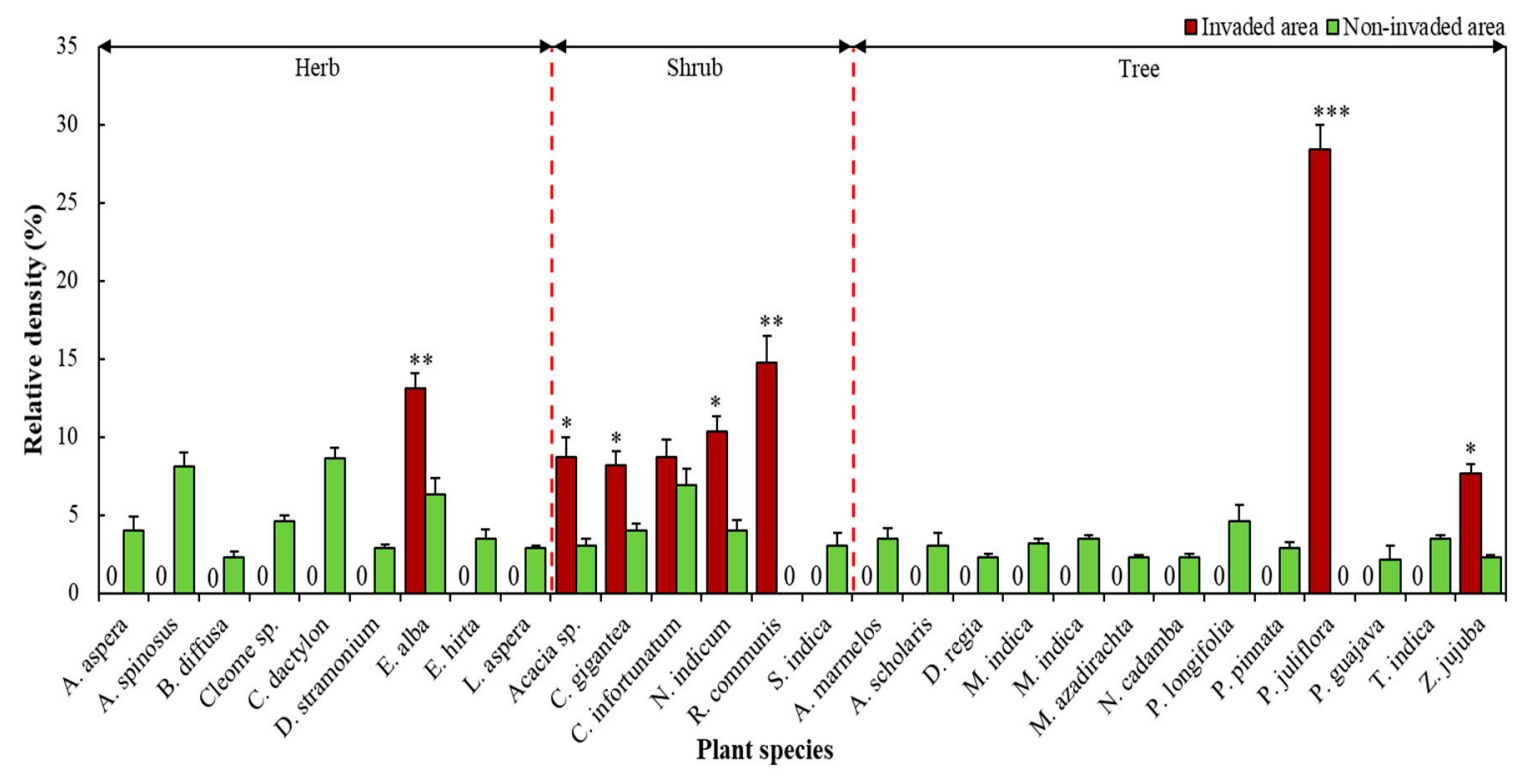

Figure 3. Relative density (RD) of the plant species (herb, shrubs and trees) found in P. juliflora-invaded and non-invaded area of Lucknow, India. Note: The value zero represent the no occurrence of particular species; whereas the asterisk above the bars represents the significance level: ${ }^{*}(p<0.05) ;{ }^{* *}(p<0.01)$.

Eight plant species belonging to seven families (Asteraceae, Mimosaceae, Apocynaceae, Lamiaceae, Euphorbiaceae, Leguminosae and Rhamnaceae) were recorded from the invaded area. In addition to the dominant species, i.e., P. juliflora, other species found in the invaded area were Acacia sp., Calotropis gigantea (L.) W.T.Aiton, Clerodendrum infortunatum L., Eclipta alba L. ex B.D.Jacks., Nerium indicum Mill., Ricinus communis L., and Ziziphus jujuba Lam. Interestingly, all of these six species except P. juliflora and $R$. communis were also found in the non-invaded region. However, the RDs of these species were higher in the P. juliflora-invaded region than the non-invaded sites (Figure 3).

Apart from the above mentioned six species, another 20 species belong to 17 different families were also found in the non-invaded area such as Achyranthes aspera L., Amaranthus spinosus L., Boerhavia diffusa L., Cleome L., Cynodon dactylon (L.) Pers., Datura stramonium L., Euphorbia hirta L., Leucas aspera Link, Stachytarpheta indica Vahl, Aegle marmelos (L.) Corrêa, Alstonia scholaris (L.) R.Br., Delonix regia (Bojer) Raf., Madhuca indica J.F.Gmel., Mangifera indica L., Melia azadirachta L., Neolamarckia cadamba (Roxb.) Bosser, Polyalthia longifolia (Sonn.) Thwaites, Pongamia pinnata (L.) Pierre, and Psidium guajava L., Tamarindus indica L.

Among the various species, the Cynodon dactylon (L.) Pers. was the most dominant species (with RD of $8.67 \%$ ) in the non-invaded area followed by Amaranthus spinosus L. (8.09\%), Clerodendrum infortunatum L. (6.94\%), Eclipta alba L. ex B.D.Jacks. (6.36\%), and so on (Figure 3). There was a significant difference $(p<0.05)$ in the species richness of the invaded and non-invaded areas $(30.50 \pm 0.65$ and $115.33 \pm 2.16$ number of species per $400 \mathrm{~m}^{2}$, respectively). As a result, the invaded area had a lower Shannon-Wiener Index $(\mathrm{H})$ for species diversity $(\mathrm{H}=1.97)$ as compared to the non-invaded region $(\mathrm{H}$ = 3.17). Moreover, the ENS was 7.17 for the P. juliflora-invaded region whereas the ENS of non-invaded region was found to be 23.79 , clearly indicates the significant difference in the phytodiversity observed in the invaded and non-invaded regions. Interestingly, there were no grasses or any other plants found beneath the canopy of the P. juliflora, depicting its strong invasion, elimination and competition potential (Figure 4a) [63-69]. The previous studies have already proven that the leaf litter and pods of P. juliflora contains allelopathic chemicals [69] facilitating its invasion by preventing the growth of other 
species (Figure 4b-c). Moreover, its strong potential to grow in diverse habitats including dump yards and other extremely degraded sites (Figure $4 \mathrm{~d}$ ) is another reason behind its widespread proliferation.
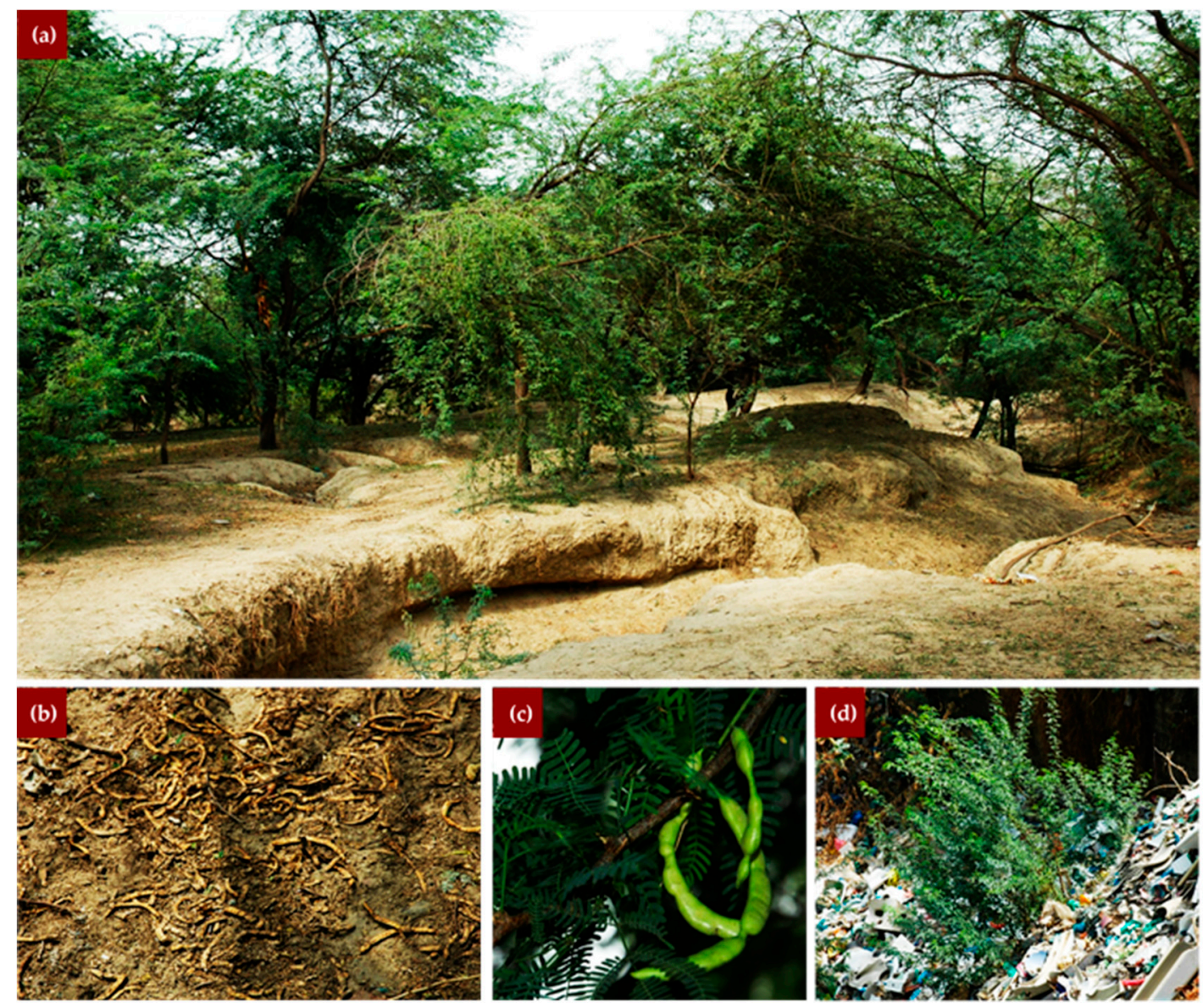

Figure 4. $P$. juliflora-invaded areas in Lucknow, Uttar Pradesh, India (a) Vast and spreading canopy of $P$. juliflora along with its string competition potential completely eliminate the ground flora; (b) Litter and (c) Pods of $P$. juliflora contain allelopathic chemicals (d) and its strong adaptation potential to grow in diverse habitat including plastic waste dump yards.

\subsection{Effect of P. juliflora Invasion on Local Livelihood}

Through direct observations via extensive field work, household surveys and the personal interviews of more than 60 respondents in each of the studied area (from both invaded and non-invaded area) covering a respondent size of over 300 peoples, it was observed that among the total 27 recorded species, only three of the species-Acacia sp., P. juliflora, and Z. jujuba-provided the lion's share of the annual fuelwood supply (i.e., $2197.30 \mathrm{~kg}$ household ${ }^{-1} \mathrm{y}^{-1}$ ) to the local residents in the invaded area, out of which, $P$. juliflora contributed more than $60 \%$ of annual fuelwood share (i.e., $1384.29 \mathrm{~kg}^{\text {household }}{ }^{-1}$ $\mathrm{y}^{-1}$ ) than the rest of the native species. This clearly shows the dependence of local residents on $P$. juliflora for their fuelwood requirements.

Similarly, the mean annual consumption of P. juliflora for the fencing of the temporary household was estimated to be $36.37 \mathrm{~kg}$ household ${ }^{-1} \mathrm{y}^{-1}$. However, in contrast to the fuelwood dependence scenario in the invaded area, the annual fuelwood consumption in the non-invaded area (3033.15 $\mathrm{kg}$ household ${ }^{-1} \mathrm{y}^{-1}$ ) was mainly contributed by local tree species such as Acacia sp., Madhuca indica, Mangifera indica, M. azadirachta, P. pinnata, and P. longifolia. Additionally, it was found that the woods of D. regia, Mangifera indica, $P$. longifolia were also being used for fencing purposes in the non-invaded area (Table 4). The lesser utilisation of woods for fencing in the non-invaded area was mainly due to the greater use of bricks and other non-wood materials by the inhabitants. Besides the utilisation of woods 
for fencing and firewood purposes, the local peoples in the invaded area were also utilising the leaf litter (for burning) and fresh pods of P. juliflora (as vegetable) and also the fruits of Z. jujuba (Table 4).

Table 4. Resource extraction and utilisation pattern by the residents in the study areas (P. juliflora-invaded area and non-invaded area in same locality).

\begin{tabular}{|c|c|c|c|c|}
\hline Site & Resource Utilisation & Plant Species & Extraction Process * & Extraction Period \\
\hline \multirow{7}{*}{$\begin{array}{l}\text { P. juliflora-invaded } \\
\text { area }\end{array}$} & \multirow{7}{*}{$\begin{array}{c}\text { Fuelwood (bark/logs)/ } \\
\text { Fodder/ } \\
\text { Fencing. } \\
\text { Pods/fruits }\end{array}$} & Acacia sp. & $\mathrm{F}, \mathrm{C}, \mathrm{L}$ & \multirow{4}{*}{$\begin{array}{l}\text { Summer and } \\
\text { winter }\end{array}$} \\
\hline & & Prosopis juliflora & $\mathrm{F}, \mathrm{L}$ & \\
\hline & & Ziziphus jujuba & $\mathrm{F}, \mathrm{C}$ & \\
\hline & & Prosopis juliflora & $\mathrm{F}, \mathrm{C}$ & \\
\hline & & Prosopis juliflora & $\mathrm{F}, \mathrm{C}$ & As requirement \\
\hline & & Prosopis juliflora & $\mathrm{P}, \mathrm{L}$ & \multirow[b]{2}{*}{ Summer } \\
\hline & & Ziziphus jujuba & $\mathrm{P}, \mathrm{L}$ & \\
\hline \multirow{21}{*}{ Non-invaded area } & \multirow{21}{*}{$\begin{array}{c}\text { Fuelwood } \\
\text { (barks/logs)/ } \\
\text { Fodder/ } \\
\text { Medicinal uses/ } \\
\text { Fencing/ } \\
\text { Fruits/edibles }\end{array}$} & Acacia sp. & $\mathrm{F}, \mathrm{C}, \mathrm{L}$ & \multirow{14}{*}{$\begin{array}{l}\text { Summer and } \\
\text { winter }\end{array}$} \\
\hline & & Madhuca indica & $\mathrm{F}, \mathrm{C}, \mathrm{L}$ & \\
\hline & & Mangifera indica & $\mathrm{F}, \mathrm{C}, \mathrm{L}$ & \\
\hline & & Melia azadirachta & $\mathrm{F}, \mathrm{C}, \mathrm{L}$ & \\
\hline & & Pongamia pinnata & $\mathrm{F}, \mathrm{C}, \mathrm{L}$ & \\
\hline & & Polyalthia longifolia & $\mathrm{C}, \mathrm{L}$ & \\
\hline & & Achyranthes aspera & G & \\
\hline & & Alstonia scholaris & $\mathrm{F}, \mathrm{G}$ & \\
\hline & & Boerhavia diffusa & $\mathrm{F}, \mathrm{G}$ & \\
\hline & & Cleome sp. & $\mathrm{F}, \mathrm{G}$ & \\
\hline & & $\begin{array}{l}\text { Clerodendrum } \\
\text { infortunatum }\end{array}$ & $\mathrm{C}, \mathrm{G}, \mathrm{Co}$ & \\
\hline & & Cynodon dactylon & $\mathrm{F}, \mathrm{G}$ & \\
\hline & & Eclipta alba & $\mathrm{F}, \mathrm{G}$ & \\
\hline & & Euphorbia hirta & F,G & \\
\hline & & Leucas aspera & $\mathrm{P}, \mathrm{U}$ & Summer and \\
\hline & & Melia azadirachta & $\mathrm{F}, \mathrm{C}, \mathrm{L}$ & winter \\
\hline & & Delonix regia & $\mathrm{F}, \mathrm{C}$ & As requirement \\
\hline & & Polyalthia longifolia & $\mathrm{F}, \mathrm{C}$ & \\
\hline & & $\begin{array}{c}\text { Neolamarckia } \\
\text { cadamba }\end{array}$ & $\mathrm{P}, \mathrm{L}$ & \\
\hline & & Aegle marmelos & $\mathrm{P}, \mathrm{L}$ & Entire season \\
\hline & & $\begin{array}{c}\text { Amaranthus } \\
\text { spinosus }\end{array}$ & $\mathrm{P}, \mathrm{L}$ & \\
\hline
\end{tabular}

However, in comparison to the ecosystem services derived by the resident peoples in $P$. juliflora-invaded sites, the non-invaded area had the greater services in terms of increased leaf litter consumption, fruits and other edibles mainly derived from Mangifera indica, N. cadamba, A. marmelos, A. spinosus, etc. Moreover, the peoples from non-invaded also benefit from additional services such as the availability of medicinal plants for the home remedy of some common diseases (Table 4). Furthermore, irrespective of the P. juliflora invasion, the local residents depend upon both P. juliflora and native plants as a key source of fodder for their livestock in both invaded (440 kg household ${ }^{-1}$ $\mathrm{y}^{-1}$ ) and the non-invaded (1526 kg household ${ }^{-1} \mathrm{y}^{-1}$ ) area. Interestingly, the local residents living in the invaded sites faced a fodder deficit of $419.97 \mathrm{~kg}$ household ${ }^{-1} \mathrm{y}^{-1}$ for their livestock whereas the residents of the non-invaded region had a fodder surplus of $157.80 \mathrm{~kg}_{\text {household }}{ }^{-1} \mathrm{y}^{-1}$ (Table 5). Although the fodder deficit to the livestock in the invaded area was fulfilled from the external sources, the survey results explicitly pointed out that the invasion of $P$. juliflora has resulted in resource scarcity 
in the P. juliflora-invaded areas, apart from other ecological impacts such as the displacement of local biodiversity.

Table 5. Estimation of fodder availability in the P. juliflora-invaded and non-invaded area to feed livestock per year (Mean $\pm \mathrm{SD})$.

\begin{tabular}{|c|c|c|c|}
\hline \multirow{2}{*}{ S1 No } & \multirow{2}{*}{ Particulars } & \multicolumn{2}{|c|}{ Study Area } \\
\hline & & P. juliflora-Invaded Area & Non-Invaded Area \\
\hline 1 & Fodder collected ${ }^{\$}\left(\right.$ kg household $\left.^{-1} \mathrm{~d}^{-1}\right)$ & $1.69 \pm 0.61$ & $4.36 \pm 1.74^{* *}$ \\
\hline 2 & Fodder demand ${ }^{\#}\left(\mathrm{~kg}\right.$ household $\left.{ }^{-1} \mathrm{y}^{-1}\right)$ & $860.67 \pm 135.24$ & $1368.20 \pm 214.99^{* *}$ \\
\hline 3 & Fodder supply (kg household $\left.{ }^{-1} \mathrm{y}^{-1}\right)$ & $440.70 \pm 159.76$ & $1526.00 \pm 143.13^{* *}$ \\
\hline 4 & Total deficit $^{\dagger}\left(\mathrm{kg}_{\text {household }}{ }^{-1} \mathrm{y}^{-1}\right)$ & $419.97 \pm 85.06^{* *}$ & $-157.80 \pm 67.41$ \\
\hline
\end{tabular}

Note: values with asterisks represents the significance level: ${ }^{*}(p<0.05) ;{ }^{* *}(p<0.01) .{ }^{\$}$ obtained from the survey results; ${ }^{\#}$ considered average fodder requirement to $4-5 \mathrm{~kg}$ livestock ${ }^{-1}$ day ${ }^{-1}[63]^{+}{ }^{\dagger}$ calculated via evaluating the difference between the fodder demand and supply and the negative value in the total deficit column represents the surplus amount of supply.

The field survey also revealed that $P$. juliflora invasion has restricted the outdoor activities of the children mainly due to the presence of piercing thorns. Although the pods of P. juliflora are rich in protein and available twice per year, there are findings that the pods have negative impacts on the health of livestock [64]. Gradually, the species has moved out of the plantation site and invaded the nearby grazing and farm lands (Figure 5) and decreased the fodder availability by displacing local species.

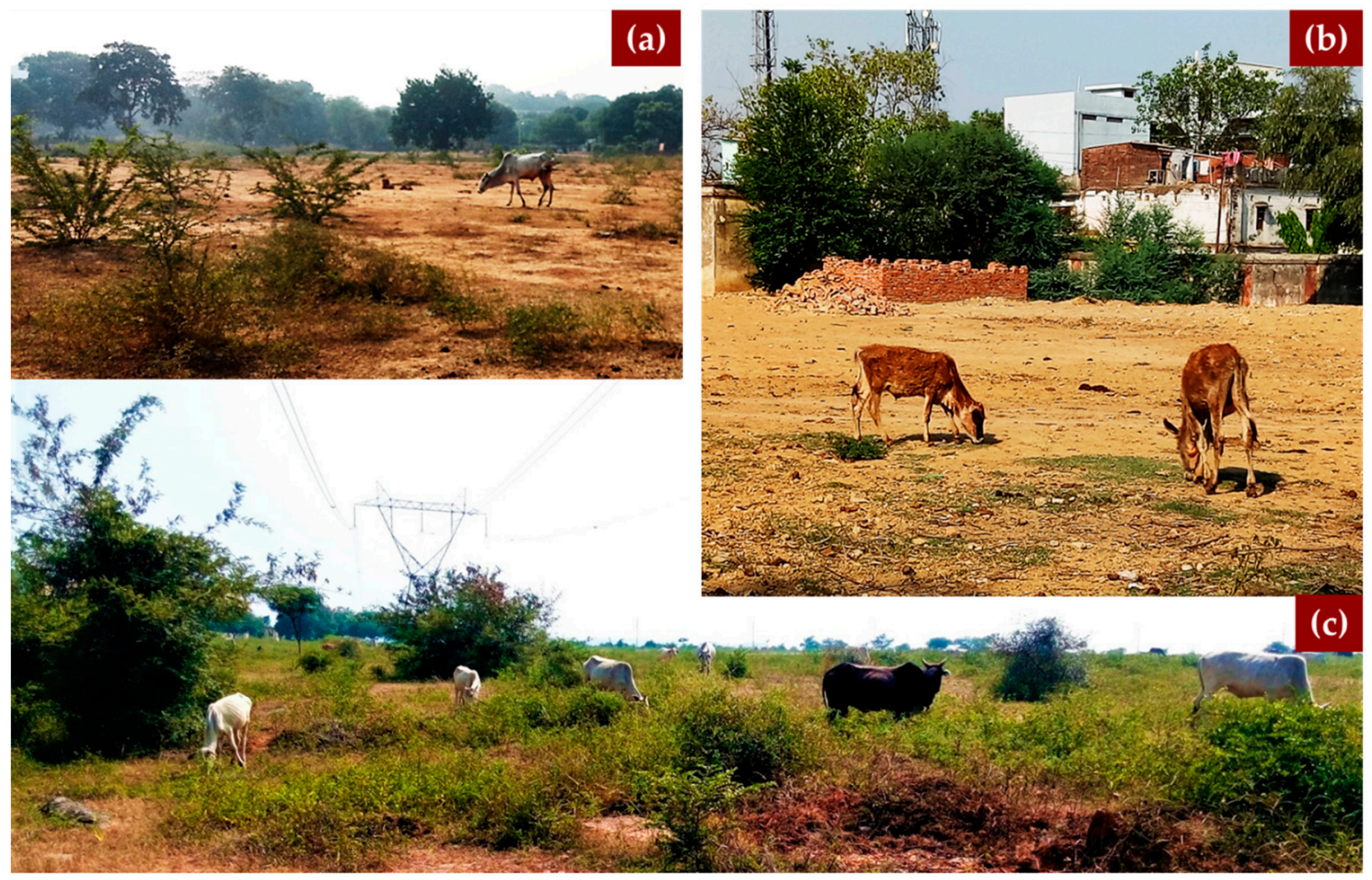

Figure 5. The effect of $P$. juliflora invasion on livestock. $(\mathbf{a}, \mathbf{b})$ the species has invaded into the nearby grazing land and reduce the fodder availability (c) than the control site by displacing local species.

\section{Discussion}

\subsection{Effect of P. juliflora Invasion on Soil Quality}

Although P. juliflora is reported as an invasive species in most of the countries, the plantation of $P$. juliflora had significantly improved the soil quality of the invaded site in Lucknow, in comparison to the non-invaded area. This is mainly due to the fact that $P$. juliflora is a nitrogen-fixing tree and has 
thereby improved the soil quality of the degraded system $[23,25,41]$. Moreover, the rapid growth of this species is also due to the inherent difference in the functional traits of P. juliflora (tetraploid, i.e., $2 \mathrm{n}$ $=4 \mathrm{x}=56$ ) in comparison to most of the native species and also to other species in this genus like $P$. pallida, P. cineraria, etc. $[65,66]$. Higher nutrient level (TOC, SOM, TN, AN, TP) in the P. juliflora-invaded soil than the non-invaded soil $(p<0.01)$ is also due to the regular addition of foliage. Previous works reported that the total phenolics in the leaf litter of $P$. juliflora resulted in an increased nutrient content in the invaded soil $[25,26,67]$. Nevertheless, it has also been reported that $P$. juliflora has the potential to alter the hydrological regime by lowering the groundwater level of the invaded area due to its rapid growth and extensive root system $[24,28,29]$. Moreover, the $P$. juliflora invasion has also reduced the microbial load in the invaded region in comparison to the control site $(p<0.01)$. Higher CFU counts in the non-invaded area may be due to the rich microbial biodiversity and high aboveground biodiversity in the non-invaded area. While there was no significant difference in the MBC at both sites, the MBN was significantly higher in the invaded area. This was mainly due to the fact $P$. juliflora is an $\mathrm{N}$-fixing tree and therefore, there may be an increased availability of $\mathrm{N}$ to the microorganisms in the rhizospheric zone. However, more studies are needed to validate the above claims. Similarly, the higher SDA content in the invaded area is also due to the higher level of SOM and TOC in the $P$. juliflora soil than at the non-invaded control site.

\subsection{Effect of P. juliflora Invasion on Local Plant Biodiversity}

The current study clearly shows that the invasion of $P$. juliflora significantly reduced the plant biodiversity of the invaded area through its displacing of the native species. There was a significant difference in the total number of plant species $(p<0.01)$ as well as the effective number of species $(p<$ $0.01)$ in the invaded and non-invaded areas. The Shannon-Wiener Index (H) also suggested the lower diversity in the P. juliflora-invaded region as compared to the non-invaded area. While the non-invaded area has 26 plant species belongs to 20 different families, the invaded area has only eight plant species belongs to seven families. The absence of grasses and other ground vegetation beneath the canopy of P. juliflora indicate the allelopathic potential of the plant species. Previous studies reported that leaf exudates of $P$. juliflora contain plant-growth inhibitors (allelochemicals) such as L-tryptophan, syringin, and (-)-lariciresinol [68]. Particularly, L-tryptophan is majorly responsible for this allelopathic effects due to its increased level in the leaf extract than the other two allelochemicals [69]. The germination assays proved that the application of L-tryptophan resulted in the $44 \%$ inhibition of the radicle growth of Lactuca sativa (lettuce) and Echinochloa crus-galli L. (barnyard grass) in comparison to the control [68]. Furthermore, it has also been observed that the leaf extract from $P$. juliflora containing L-tryptophan $(17.9 \mu \mathrm{M})$ has reduced the root growth in lettuce and barnyard grass [69]. Hence, it is well established that L-tryptophan from the leaf litters of $P$. juliflora plays an important role whereas syringin and (-)-lariciresinol plays a supplementary role in the allelopathic activity of $P$. juliflora leaves. Apart from these allelochemicals, there are also some plant-growth inhibitory alkaloids such as 3 "'"-oxojuliflorine (3"'"-oxojuliprosopine), secojuliprosopinal, juliprosine, julifloricine, juliflorine, and juliprosopine found in the extracts of P. juliflora leaves [70-75]. Moreover, it has been reported that the bacterial and fungal isolates from the leaves of $P$. juliflora had significantly reduced the growth of Brassica juncea and Chloris dolichostachya [25] and the leaf litter addition had a negative impact on the growth of native plants in India such as Gum Arabic tree, Indian mustard, Rapeseed, etc. [25].

The severity of $P$. juliflora invasion is that this species is not only occupying the empty niche, but also affecting nearby productive systems and gradually displacing the native species. For example, P. juliflora has invaded the Baadu region of Ethiopia, taking over almost $8 \%$ of total wetland area within a year [76]. However, within the span of 13 years, the species has invaded to almost $40 \%$ of the wetland area [76]. Such invasions are negatively affecting the provisioning services like food, fodder, fuelwood, water, etc., and thereby affecting the food security and livelihood of nomads and agro-pastoralists [77-80]. Although P. juliflora was deliberately introduced for the restoration of extremely degraded soil where the growth and survival other species were not possible, it has 
gradually invaded the unintended sites and caused ecosystem disservices [76,78]. Therefore, the future introduction of species warrants a detailed ecological risk assessment, especially under the changing climatic condition.

\subsection{Effect of P. juliflora Invasion on Local Livelihood}

The present study also reported that $P$. juliflora invasion negatively affects the livelihood of local people. While $P$. juliflora is mainly used as a fuelwood $\left(1384.29 \mathrm{~kg}_{\text {household }}^{-1} \mathrm{y}^{-1}\right)$ in the invaded region, its prominence has significantly reduced other services such as fodder, medicine, fencing, fruits/edibles, etc., which are also essential for the resource-poor local residents for their sustenance. On the other side, the non-invaded area provided more services to the local people either in terms of fuelwood (i.e., $3033.15 \mathrm{~kg}$ household ${ }^{-1} \mathrm{y}^{-1}$ ) or the other aforesaid services. Moreover, the non-invaded area provided a surplus fodder of $157.80 \mathrm{~kg}_{\text {household }}^{-1} \mathrm{y}^{-1}$ for the livestock, whereas the invaded area was under the deficit of $419.97 \mathrm{~kg}$ household ${ }^{-1} \mathrm{y}^{-1}$. Apart from these shortcomings, P. juliflora has far-reaching adverse impacts on the livestock, as its ethanolic pods and leaves are reported to be toxic [78-81]. There are findings that the leaves cause diarrhoea in animals [82], thorns causes injuries and even the death to the animals [83].

The above findings clearly show that $P$. juliflora is having both positive as well as negative effects and, therefore, such invasive species cannot be prioritized for any national or regional biofuel programs. Instead, native species such as Miscanthus, Panicum virgatum, Azadirachta indica, Pongamia pinnata, Madhuca indica, Tectona grandis, Dalbergia sissoo, Agave sisalana, Simarouba glauca, Leucaena leucocephala, Calophyllum inophyllum, etc., having multipurpose environmental benefits, must be utilised for the restoration of degraded lands for attaining UN-SDGs.

\section{Conclusions}

Our study clearly indicates that $P$. juliflora has many adaptive traits for surviving in marginal, and even extremely degraded lands. While it has the potential to restore the fertility of degraded lands up to a certain extent and provides fuelwood and fodder to the local people, there is a hidden but known danger of the use of this species for the land restoration program, because P. juliflora also has several invasive traits. As a result, $P$. juliflora can grow-out from the introduced area to the nearby productive systems and can reduce the ecosystem services of the invaded sites by displacing the native biodiversity. The distribution study clearly shows that $P$. juliflora is now found in more than 103 countries and has become an invasive species in many continents. Therefore, utmost care must be taken to utilise this species for the future land restoration programs (especially targeted during the United Nations Decade on Ecosystem Restoration, 2021-2030) and suitable eradication programs must be urgently framed for the already-invaded sites.

Author Contributions: P.C.A., S.A.E. and A.E.-K. designed the study. S.A.E. performed the surveys and samplings. All authors contributed in writing and final preparation of the manuscript. All authors have read and agreed to the published version of the manuscript.

Funding: No financial support.

Acknowledgments: S.A.E. thankfully acknowledge the financial support from UGC (SRF) for doing PhD work. Thanks are also due to Head, DESD and Director, IESD, BHU for support and encouragement.

Conflicts of Interest: Authors do not have any conflicts of interest.

\section{References}

1. Rakshit, A.; Sarkar, B.; Abhilash, P.C. Soil Amendments for Sustainability: Challenges and Perspectives, 1st ed.; CRC Press: Boca Raton, FL, USA, 2018; p. 428.

2. Edrisi, S.A.; Abhilash, P.C. Book review: Socio-economic impacts of bioenergy production. Front. Bioeng. Biotechnol. 2015, 3, 174. [CrossRef] 
3. Plieninger, T.; Gaertner, M. Harnessing degraded lands for biodiversity conservation. J. Nat. Conserv. 2011, 19, 18-23. [CrossRef]

4. Nkonya, E.; Mirzabaev, A.; Von Braun, J. Economics of Land Degradation and Improvement: A Global Assessment for Sustainable Development; Springer: Cham, Switzerland, 2016; p. 686.

5. Tripathi, V.; Edrisi, S.A.; O'Donovan, A.; Gupta, V.K.; Abhilash, P.C. Bioremediation for Fueling the Biobased Economy. Trend Biotechnol. 2016, 34, 775-777. [CrossRef] [PubMed]

6. Dubey, R.K.; Tripathi, V.; Edrisi, S.A.; Bakshi, M.; Dubey, P.K.; Singh, A.; Verma, J.P.; Singh, A.; Sarma, B.K.; Raskhit, A.; et al. Role of Plant Growth Promoting Microorganisms in Sustainable Agriculture and Environmental Remediation. In Advances in PGPR Research; Sarma, B.K., Singh, H.B., Keswani, C., Eds.; Centre for Agriculture and Biosciences International (CABI): Wallingford, UK, 2017; p. 466. ISBN 9781786390325.

7. Edrisi, S.A.; Tripathi, V.; Abhilash, P.C. Performance analysis and soil quality indexing for Dalbergia sissoo Roxb. grown in marginal and degraded land of eastern Uttar Pradesh, India. Land 2019, 8, 63. [CrossRef]

8. Xie, H.; Zhang, Y.; Wu, Z.; Lv, T. A Bibliometric Analysis on Land Degradation: Current Status, Development, and Future Directions. Land 2020, 9, 28. [CrossRef]

9. ICAR. Degraded and Wastelands of India; Indian Council of Agricultural Research: New Delhi, India, 2010; p. 167. Available online: https://icar.org.in/files/Degraded-and-Wastelands.pdf (accessed on 10 January 2020).

10. ICRISAT. Agri-Buzz Blog: Bioreclamation of Degraded Lands: Restoring Roots, Rights and Resilience in Niger. Available online: https://www.icrisat.org/bioreclamation-of-degraded-lands-restoring-roots-rightsand-resilience-in-niger/ (accessed on 16 October 2017).

11. Besseau, P.; Graham, S.; Christophersen, T. (Eds.) Restoring Forests and Landscapes: The Key to a Sustainable Future; Global Partnership on Forest and Landscape Restoration (GPFLR): Vienna, Austria, 2018; p. 25.

12. Keesstra, S.; Mol, G.; de Leeuw, J.; Okx, J.; Molenaar, C.; de Cleen, M.; Visser, S. Soil-Related Sustainable Development Goals: Four Concepts to Make Land Degradation Neutrality and Restoration Work. Land 2018, 7, 133. [CrossRef]

13. Tianjiao, F.; Wei, W.; Liding, C.; Keesstra, S.D.; Yang, Y. Effects of land preparation and plantings of vegetation on soil moisture in a hilly loess catchment in China. Land Degrad. Dev. 2018, 29, 1427-1441. [CrossRef]

14. Novara, A.; Pulido, M.; Rodrigo-Comino, J.; Di Prima, S.; Smith, P.; Gristina, L.; Gimenez-Morera, A.; Terol, E.; Salesa, D.; Keesstra, S. Long-term organic farming on a citrus plantation results in soil organic carbon recovery. Cuad. Investig. Geogr. 2019, 45, 271-286. [CrossRef]

15. Edrisi, S.A.; Abhilash, P.C. Sustainable bioenergy production from woody biomass: Prospects and promises. J. Clean. Prod. 2015, 102, 558-559. [CrossRef]

16. Edrisi, S.A.; Abhilash, P.C. Exploring marginal and degraded lands for biomass and bioenergy production: An Indian scenario. Renew. Sustain. Energy Rev. 2016, 54, 1537-1551. [CrossRef]

17. Lefcheck, J.S.; Byrnes, J.E.; Isbell, F.; Gamfeldt, L.; Griffin, J.N.; Eisenhauer, N.; Hensel, M.J.; Hector, A.; Cardinale, B.J.; Duffy, J.E. Biodiversity enhances ecosystem multifunctionality across trophic levels and habitats. Nat. Commun. 2015, 6, 6936. [CrossRef] [PubMed]

18. Paini, D.R.; Sheppard, A.W.; Cook, D.C.; De Barro, P.J.; Worner, S.P.; Thomas, M.B. Global threat to agriculture from invasive species. Proc. Nat. Acad. Sci. USA 2016, 113, 7575-7579. [CrossRef] [PubMed]

19. Early, R.; Bradley, B.A.; Dukes, J.S.; Lawler, J.J.; Olden, J.D.; Blumenthal, D.M.; Gonzalez, P.; Grosholz, E.D.; Ibañez, I.; Miller, L.P.; et al. Global threats from invasive alien species in the twenty-first century and national response capacities. Nat. Commum. 2016, 7, 12485. [CrossRef] [PubMed]

20. Hanley, N.; Roberts, M. The economic benefits of invasive species management. People Nat. 2019, 1, $124-137$. [CrossRef]

21. MNRE. National Policy on Biofuels, Ministry of New and Renewable Energy; Government of India: New Delhi, India, 2009.

22. Baka, J. What wastelands? A critique of biofuel policy discourse in South India. Geoforum 2014, 54, 315-323. [CrossRef]

23. El-Keblawy, A.; Al-Rawai, A. Impacts of the invasive exotic Prosopis juliflora (Sw.) D.C. on the native flora and soils of the UAE. Plant Ecol. 2007, 190, 23-35. [CrossRef]

24. El-Fadl, M.A. Management of Prosopis Juliflora for Use in Agroforestry Systems in the Sudan. Bachelor's Thesis, University of Helsinki, Helsinki, Finland, 1997; p. 107. 
25. Kaur, R.; Gonzales, W.L.; Llambi, L.D.; Soriano, P.J.; Callaway, R.M.; Rout, M.E.; Gallaher, T.J.; Inderjit. Community Impacts of Prosopis juliflora Invasion: Biogeographic and Congeneric Comparisons. PLoS ONE 2012, 7, e44966. [CrossRef]

26. Al-Humaid, A.I.; Warrag, M.O.A. Allelopathic effects of mesquite (Prosopis juliflora) foliage on seed germination and seedling growth of bermudagrass (Cynodon dactylon). J. Arid Environ. 1998, 38, 237-243. [CrossRef]

27. Maundu, P.; Kibet, S.; Morimoto, Y.; Imbumi, M.; Adeka, R. Impact of Prosopis juliflora on Kenya's semi-arid and arid ecosystems and local livelihoods. Biodivers 2009, 10, 33-50. [CrossRef]

28. Gallaher, T.; Merlin, M. Biology and impacts of Pacific Island invasive species Prosopis pallida and Prosopis juliflora (Algar roba, Mesquite, Kiawe) (Fabaceae). Pac. Sci. 2010, 64, 489-526. [CrossRef]

29. Dzikiti, S.; Schachtschneider, K.; Naiken, V.; Gush, M.; Moses, G.; Le Maitre, D.C. Water relations and the effects of clearing invasive Prosopis trees on groundwater in an arid environment in the Northern Cape, South Africa. J. Arid Environ. 2013, 90, 103-113. [CrossRef]

30. Pasiecznik, N.; Felker, P.; Harris, P.; Harsh, L.; Cruz, G.; Tewari, J.; Cadoret, K.; Maldonado, L. The Prosopis Juliflora-Prosopis Pallida Complex: A Monograph; HDRA: Coventry, UK, 2001; p. 172.

31. Lowe, S.; Browne, M.; Boudjelas, S.; De Poorter, M. 100 of the World's Worst Invasive Alien Species: A Selection from the Global Invasive Species Database; Invasive Species Specialist Group; IUCN: Auckland, New Zealand, 2000; Volume 12, p. 12.

32. Shackleton, R.T.; Le Maitre, D.C.; Pasiecznik, N.M.; Richardson, D.M. Prosopis: A global assessment of the biogeography, benefits, impacts and management of one of the world's worst woody invasive plant taxa. AoB Plants 2014, 6, plu027. [CrossRef]

33. Shiferaw, H.; Bewket, W.; Alamirew, T.; Zeleke, G.; Teketay, D.; Bekele, K.; Schaffner, U.; Eckert, S. Implications of land use/land cover dynamics and Prosopis invasion on ecosystem service values in Afar Region, Ethiopia. Sci. Total Environ. 2019, 675, 354-366. [CrossRef]

34. Shackleton, R.T.; Le Maitre, D.C.; Van Wilgen, B.W.; Richardson, D.M. The impact of invasive alien Prosopis species (mesquite) on native plants in different environments in South Africa. S. Afr. Bot. 2015, 97, $25-31$. [CrossRef]

35. Keller, P.; Lodge, M.; Lewis, M.; Shogren, J. Bioeconomics of Invasive Species: Integrating Ecology, Economics, Policy, and Management; University of Oxford: Oxford, UK, 2010.

36. Prasad, M.N.V.; Tewari, J.C. Prosopis juliflora (SW) DC: Potential for Bioremediation and Bioeconomy. In Bioremediation and Bioeconomy; Prasad, M.N.V., Ed.; Elsevier: Amsterdam, The Netherlands, 2016; pp. 49-76.

37. El-Fadl, M.A.; Luukkanen, O. Field studies on ecological strategies of Prosopis juliflora in a dry land ecosystem: 1. A leaf gas exchange approach. J. Arid Environ. 2006, 66, 1-15. [CrossRef]

38. Zimmermann, H.G. Biological control of Prosopis, Prosopis spp. (Fabaceae), in South Africa. Agric. Ecosyst. Environ. 1991, 37, 175-186. [CrossRef]

39. Choge, S.K.; Ngujiri, F.D.; Kuria, M.N.; Busaka, E.A.; Muthondeki, J.K. The Status and Impact of Prosopis spp.; KEFRI: Kenya, Nairobi, 2002.

40. Laxen, J. Is Prosopis a curse or a blessing? An ecological and economic analysis of an invasive alien tree species in Sudan. In Tropical Forestry Reports; Lukkanan, O., Ed.; VITRI, University of Helsinki: Helsinki, Finland, 2007; pp. 1-199.

41. CAZRI. Prosopis juliflora: A Valuable Species for Arid and Semi-arid Tropics. In Discussion Papers for National Workshop on Prqsopis juliflora: Past, Present and Future; ICAR-CAZRI (Indian Council of Agricultural Research, Central Arid Zone Research Institute): Jodhpur, India, 2011; pp. 7-44.

42. Pysek, P.; Richardson, D.M.; Rejmanek, M.; Webster, G.L.; Williamson, M.; Kirschner, J. Alien plants in checklists and floras: Towards better communication between taxonomists and ecologists. Taxon 2004, 53, 131-143. [CrossRef]

43. Ahmad, A.; Khan, K.A.; Ahmad, V.U.; Oazi, S. Antibacterial activity of juliflorine isolated from Prosopis juliflora. Planta Med. 1986, 52, 285-288. [CrossRef]

44. Bhojvaid, P.P.; Timmer, V.R. Soil dynamics in an age sequence of Prosopis juliflora planted for sodic soil restoration in India. For. Ecol. Manag. 1998, 106, 181-193. [CrossRef]

45. Prabha, D.S.; Dahms, H.U.; Malliga, P. Pharmacological potentials of phenolic compounds from Prosopis spp.-a. J. Coast. Life Med. 2014, 2, 918-924. [CrossRef] 
46. McLean, E.O. Soil pH and lime requirement. In Methods of Soil Analysis. Part 2, 2nd ed.; Page, A.L., Ed.; ASA and SSSA: Madison, WI, USA, 1982; pp. 199-224.

47. Blake, G.R.; Harte, K.H. Bulk density. In Methods of Soil Analysis. Part 1. Physical and Mineralogical Methods, 2nd ed.; Klute, A., Ed.; American Society of Agronomy and Soil Science Society of America: Madison, WI, USA, 1986; pp. 363-375.

48. Toth, S.J.; Prince, A.L. Estimation of cation-exchange capacity and exchangeable Ca, K, and Na contents of soils by flame photometer techniques. Soil Sci. 1949, 67, 439-446. [CrossRef]

49. Walkley, A. A critical examination of a rapid method for determining organic carbon in soils: Effect of variations in digestion conditions and of organic soil constituents. Soil Sci. 1947, 63, 251-264. [CrossRef]

50. Kalra, Y.P.; Maynard, D.G. Methods Manual for Forest Soil and Plant Analysis; Information Report NOR-X-319; Northern Forestry Centre: Edmonton, AB, Canada, 1991; p. 116.

51. Subbiah, B.V.; Asija, G.L. A rapid procedure for the determination of available nitrogen in soils. Curr. Sci. 1956, 25, 259-260.

52. Olsen, S.R.; Sommers, L.E. Phosphorus. Methods of Soil Analysis, Part 2-Chemical and Microbiological Properties, 2nd ed.; Page, A.L., Ed.; American Society of Agronomy, Soil Science Society of America: Madison, WI, USA, 1982.

53. Vance, E.D.; Brookes, P.C.; Jenkinson, D.S. An extraction method for measuring soil microbial biomass C. Soil Biol. Biochem. 1987, 19, 703-707. [CrossRef]

54. Brookes, P.C.; Landman, A.; Pruden, G.; Jenkinson, D.S. Chloroform fumigation and the release of soil nitrogen: A rapid direct extraction method to measure microbial biomass nitrogen in soil. Soil Biol. Biochem. 1985, 17, 837-842. [CrossRef]

55. Casida, L.E., Jr.; Klein, D.A.; Santoro, T. Soil dehydrogenase activity. Soil Sci. 1964, 98, 371-376. [CrossRef]

56. Murthy, H.M.R.; Manomani, H.K. Aerobic degradation of technical hexachlorocyclohexane by a defined microbial consortium. J. Hazard. Mater. 2007, 149, 18-25. [CrossRef]

57. Adhikari, M.; Nagata, S.; Adhikari, M. Rural household and forest: An evaluation of household's dependency on community forest in Nepal. J. For. Res. 2004, 9, 33-44. [CrossRef]

58. Maikhuri, R.K.; Semwal, R.L.; Singh, A.; Nautiyal, M.C. Wild fruits as a contribution to sustainable rural development: A case study from the Garhwal Himalaya. Int. J. Sust. Dev. World Ecol. 1994, 1, 56-68. [CrossRef]

59. Sundriyal, R.C.; Sharma, E. Anthropogenic pressure on tree structure and biomass in the temperate forest of Mamlay watershed in Sikkim. For. Ecol. Manag. 1996, 81, 113-134. [CrossRef]

60. IBM SPSS. IBM SPSS Statistics 19: A Brief Guide; SPSS Inc.: Chicago, IL, USA, 2010.

61. SPSS. SPSS Version 16.0.2; SPSS Inc.: Chicago, IL, USA, 2008; Available online: https://dl.acm.org/doi/abs/10. 5555/542499 (accessed on 26 January 2020).

62. Waksman, S.A. Microbiological analysis of soil as an index of soil quality. III. Influence of fertilization upon numbers of microorganisms in soil. Soil Sci. 1992, 14, 321-346. [CrossRef]

63. Mahanta, S.K. Economic Balanced Rations for Dairy Animals; ICAR-Indian Grassland and Fodder Research Institute: Jhansi, India, 2017; p. 35.

64. Câmara, A.C.L.; Afonso, J.A.B.; Riet-Correa, F. Rational uses of mesquite (Prosopis juliflora) and the importance of spontaneous poisoning by the pods in ruminants from Pernambuco. In Poisoning by Plants, Mycotoxins and Related Toxins; Riet-Correa, F., Pfister, J., Schild, A.L., Eds.; CAB International: London, UK 2011; pp. $295-301$.

65. Wardle, D.A.; Bardgett, R.D.; Callaway, R.M.; Van der Putten, W.H. Terrestrial ecosystem responses to species gains and losses. Science 2011, 332, 1273-1277. [CrossRef] [PubMed]

66. Trenchard, L.J.; Harris, P.J.C.; Smith, S.J.; Pasiecznik, N.M. A review of ploidy in the genus Prosopis (Leguminosae). Bot. J. Linn. Soc. 2008, 156, 425-438. [CrossRef]

67. Seastedt, T.R.; Callaway, R.M.; Pollock, J.; Kaur, J. Allelopathy and plant invasions: Traditional, congeneric, and biogeographical approaches. Biol. Invasions 2008, 10, 875-890. [CrossRef]

68. Nakano, H.; Fujii, Y.; Suzuki, T.; Yamada, K.; Kosemura, S.; Yamamura, S.; Hasegawa, K. A growth-inhibitory substance exuded from freeze-dried mesquite (Prosopis juliflora (Sw.) DC.) leaves. Plant Growth Regul. 2001, 33, 165-168. [CrossRef]

69. Nakano, H. Plant growth inhibitors from mesquite (Prosopis juliflora). In Desert Plants; Ramawat, K.G., Ramawat, K., Eds.; Springer: Berlin/Heidelberg, Germany, 2010; pp. 341-352.

70. Ahmad, V.U.; Mohammad, Z.G. Studies on the structure of juliflorine. J. Chem. Soc. Pak. 1979, 1, 137-138. 
71. Ott-Longoni, R.; Viswanathan, N.; Hesse, M. Die Konstitution des Alkaloides Juliprosopin aus Prosopis juliflora A. DC. Helv. Chim. Acta 1980, 63, 2119-2129. [CrossRef]

72. Ahmad, V.U.; Sultana, A.; Qazi, S. Alkaloids from the leaves of Prosopis juliflora. J. Nat. Prod. 1989, 52, 497-501. [CrossRef]

73. Datwyler, P.; Ott-Longoni, R.; Schopp, E.; Hesse, M. Uber Juliprosin, ein weiteres Alkaloid aus Prosopis juliflora A. DC. Helv. Chim. Acta 1981, 64, 1959-1963. [CrossRef]

74. Tapia, A.; Feresin, G.E.; Bustos, D.; Astudillo, L.; Theoduloz, C.; Schmeda-Hirschmann, G. Biologically active alkaloids and a free radical scavenger from Prosopis species. J. Ethnopharmacol. 2000, 71, 241-246. [CrossRef]

75. Aqeel, A.; Khursheed, A.K.; Viqaruddin, A.; Sabiha, Q. Antimicrobial activity of julifloricine isolated from Prosopis juliflora. Arzneim. Forsch. Drug Res. 1989, 39, 652-655.

76. Ayanu, Y.; Jentsch, A.; Müller-Mahn, D.; Rettberg, S.; Romankiewicz, C.; Koellner, T. Ecosystem engineer unleashed: Prosopis juliflora threatening ecosystem services? Reg. Environ. Chang. 2014, 15, 155-167. [CrossRef]

77. Admasu, D. Invasive Plants and Food Security: The case of Prosopis juliflora in the Afar region of Ethiopia. FARM-Africa, IUCN Report. 2008. Available online: http://cmsdata.iucn.org/downloads/invasive_plants_ and_food_security__final.pdf (accessed on 3 March 2019).

78. Amdihun, A.; Tadesse, G.; Peden, D.; Getahun, Y. Invasive Plant Prosopis Juliflora Expansion on Farm and Grazing Land in Ethiopia: A Threat to Pastoral Grazing Land; International Livestock Research Institute: Addis Ababa, Ethiopia, 2010; Available online: http://www.docstoc.com/docs/23533265/Prosopis-Juliflora-distribution-inAwash-River-Basin-Ethiopia (accessed on 22 March 2011).

79. Berhanu, A.; Tesfaye, G. The Prosopis dilemma, impacts on dryland biodiversity and some controlling methods. J. Drylands 2006, 1, 158-164.

80. Yohannes, T.; Awas, T.; Demisew, S. Survey and documentation of the potential and actual invasive alien plant species and other biological threats to biodiversity in Awash National Park, Ethiopia. Manag. Biol. Invasions 2011, 2, 3-14. [CrossRef]

81. Wamburu, R.W.; Kareru, P.G.; Mbaria, J.M.; Nyaga, G.; Rechab, S.O. Spectrometric detection of organic compounds and toxicity of ethanolic leaves extracts of Prosopis juliflora. Chem. Mater. Res. 2015, 7, 21-25.

82. Silva, V.D.A.; Pitanga, B.P.S.; Nascimento, R.P.; Souza, C.S.; Coelho, P.L.; Menezes, F.N.; Silva, A.M.M.; Costa, M.F.D.; El-Bacha, R.S.; Velozo, E.S.; et al. Juliprosopine and juliprosine from Prosopis juliflora leaves induce mitochondrial damage and cytoplasmic vacuolation on co-cultured glial cells and neurons. Chem. Res. Toxicol. 2013, 26, 1810-1820. [CrossRef]

83. Wamburu, R.W.; Kareru, P.G.; Mbaria, J.M.; Njonge, F.K.; Nyaga, G.; Rechab, S.O. Acute and sub-Acute toxicological evaluation of ethanolic leaves extract of Prosopis juliflora (Fabaceae). J. Nat. Sci. Res. 2013, 3, 8-15.

(C) 2020 by the authors. Licensee MDPI, Basel, Switzerland. This article is an open access article distributed under the terms and conditions of the Creative Commons Attribution (CC BY) license (http://creativecommons.org/licenses/by/4.0/). 